\title{
Is bacteriological examination by skin smear necessary in all paucibacillary leprosy patients in mass control programmes?
}

\author{
P S RAO, V EKAMBARAM*, B N REDDY, \\ P KRISHNAMOORTHY, S K SURESH KUMAR \& \\ A DUTTA \\ Central Leprosy Teaching \& Research Institute, Chengalpattu, \\ Tamil Nadu, India 603001 ; and *23, V P Colony, Madras 23, India
}

Accepted for publication 1 May 1991

\begin{abstract}
Summary Skin smear bacteriological examination results of 11,255 paucibacillary leprosy patients from 8 leprosy control units under the National Leprosy Eradication Programme (NLEP) in South India and the Outpatient Department (OPD) of the Central Leprosy Teaching \& Research Institute (CLT\&RI), Chengalpattu, between 1987 and 1989 were collected and analysed. Only $0.05 \%$ of the smears from leprosy control units and $2.49 \%$ from the OPD of CLT\&RI were found to be positive. Not a single smear from indeterminate, tuberculoid and pure neuritic types of leprosy out of 8263 examined was found positive under field conditions. The relevance of carrying out routine bacteriological examination in mass leprosy control programmes is discussed.
\end{abstract}

\section{Introduction}

Leprosy patients of all types are being grouped into paucibacillary (PB) and multibacillary (MB) for treatment purposes with the advent of multidrug therapy (MDT). Indeterminate (I) and tuberculoid (T) under the Madrid classification, indeterminate (I), tuberculoid (TT) and borderline-tuberculoid (BT) leprosy in the Ridley-Jopling classification whenever diagnosed clinically or histopathologically, with a bacteriological index of $<2+$ on the Ridley-Jopling scale at any site were included in the PB leprosy group ${ }^{1}$. Indeterminate, tuberculoid, borderline-tuberculoid (BT) and pure neuritic (PN) leprosy patients are grouped under PB as per consensus classification of the Indian Association of leprologists $1981^{2}$. However, it was recommended that any case belonging to I, TT or BT leprosy groups according to the Ridley-Jopling classification with skinsmear positivity will be classified as MB for the purpose of MDT Programmes. ${ }^{3}$ The guidelines under NLEP in India also states that all skin-smear positive patients irrespective of their clinical classification should be brought under MB MDT. As a result, it becomes absolutely necessary to carry out the bacteriological examination of all leprosy cases detected before giving them treatment. Most of the textbooks on leprosy state that skinsmear results are seldom positive in I and TT types which form the bulk of PB cases. ${ }^{4-7}$ 
There is no literature on the extent of positivity of skin smears of patients who are I, TT, BT and PN under field conditions in mass programmes on a large scale and at routine examinations in out-patient departments (OPD) in leprosy institutions. An attempt has been made in this paper to find out the above information and analyse it as to the relevance of routine bacteriological skin smear examination in PB leprosy patients in mass control programmes.

\section{Materials and methods}

Under NLEP in India, on detection of the new leprosy cases activity or passively, they are confirmed and classified clinically by medical officers. A smear examination is then carried out for allocation to either PB or MB MDT regimens. Some of the medical officers working in leprosy control units in Krishna, Cuddappah and Chittoor Districts in Andhra Pradesh State were requested through their district leprosy officer to furnish information relating to bacteriological examination results of newly detected PB leprosy patients (I, TT, BT \& PN) for the years 1987, 1988 and 1989 through a format sent to them. The medical officers were personally briefed and requested to collect information by examining individual patient care-cards of all new cases detected during the period under reference. They were specifically told to include all such I, TT, BT, and PN cases receiving $\mathrm{MB}$ treatment in the data furnished by them. The same information has been collected from the Field Operational Area and OPD of CLT\&RI for the above period. Similar information from a leprosy control unit in Tamil Nadu State has been collected from the database which has been computerized as a part of an on-going in-depth evaluation of MDT project in the Institute. The units were picked up as per operational convenience and to render data of reasonable validity. The smears were collected from a minimum of 3 sites and read on the Ridley-Jopling scale as per NLEP guidelines by a trained laboratory technician at each of the centres reported. A limited cross-check of about 5\% smears was reported by one unit (Machilipatnam) on the smear examination at the District Leprosy Office of Krishna District with no variation of results. All the units mentioned above have been implementing MDT projects since 1987.

\section{Results}

Information collected from 8 leprosy control units (including the field operational area of the Institute) and the OPD of CLT\&RI were summarized in Table 1.

Out of the 12,686 new cases detected/reported between 1987 and 1989, in 11,255 $(88.7 \%)$ patients the slit-skin smear bacteriological examination has been carried out. Coverage of examination ranged from $58.6 \%$ in the CLT\&RI field area to $100 \%$ in a number of the centres (Pileru, Palamaner, Produturu \& OPD of CLT\&RI).

The total positive cases were $39(0 \cdot 35 \%)$ of the total examined cases. The positivity in various centres ranged from $0 \%$ in several units to $2.49 \%$ in OPD of CLT\&RI. In all the field units positivity was reported as $0 \%$ except in Pileru and Palamaner units where the positivity was $0 \cdot 25 \%$ and $0 \cdot 29 \%$ respectively. 
Table 1. New PB cases detected skin smears examined and positive cases in different centres, 1987-89

\begin{tabular}{|c|c|c|c|c|c|c|c|c|c|c|c|c|c|c|c|c|}
\hline \multirow{2}{*}{ S.no. } & \multirow{2}{*}{$\begin{array}{l}\text { Name of the leprosy } \\
\text { control unit }\end{array}$} & \multicolumn{3}{|c|}{ Indeterminate } & \multicolumn{3}{|c|}{ Tuberculoid } & \multicolumn{3}{|c|}{$\begin{array}{l}\text { Borderline- } \\
\text { tuberculoid }\end{array}$} & \multicolumn{3}{|c|}{ Pure neuritic } & \multicolumn{3}{|c|}{ Total } \\
\hline & & $\mathrm{R}$ & $\mathrm{E}$ & $\mathrm{P}$ & $\mathrm{R}$ & $\mathrm{E}$ & $\mathrm{P}$ & $\mathrm{R}$ & $\mathrm{E}$ & $P$ & $\mathrm{R}$ & E & $\mathrm{P}$ & $\mathrm{R}$ & E & $\mathrm{P}$ \\
\hline 1 & Nuzvid & 15 & $\begin{array}{c}6 \\
(40 \cdot 0)\end{array}$ & 0 & 1025 & $\begin{array}{l}1014 \\
(98 \cdot 9)\end{array}$ & 0 & 572 & $\begin{array}{l}433 \\
(75 \cdot 7)\end{array}$ & 0 & 11 & $\begin{array}{c}6 \\
(54 \cdot 5)\end{array}$ & 0 & 1623 & $\begin{array}{l}1459 \\
(89 \cdot 9)\end{array}$ & 0 \\
\hline 2 & Machilipatnam & 1188 & $\begin{array}{l}962 \\
(81 \cdot 0)\end{array}$ & 0 & 1314 & $\begin{array}{l}1012 \\
(77 \cdot 0)\end{array}$ & 0 & 406 & $\begin{array}{l}260 \\
(64 \cdot 0)\end{array}$ & 0 & 202 & $\begin{array}{l}147 \\
(72 \cdot 8)\end{array}$ & 0 & 3110 & $\begin{array}{l}2381 \\
(76 \cdot 6)\end{array}$ & 0 \\
\hline 3 & Assisi & 10 & $\begin{array}{c}4 \\
(40)\end{array}$ & 0 & 989 & $\begin{array}{l}706 \\
(71 \cdot 4)\end{array}$ & 0 & 19 & $\begin{array}{c}19 \\
(100)\end{array}$ & 0 & 1 & $\begin{array}{c}1 \\
(100)\end{array}$ & 0 & 1019 & $\begin{array}{l}730 \\
(71 \cdot 6)\end{array}$ & 0 \\
\hline 4 & Pileru & 0 & 0 & 0 & 698 & $\begin{array}{c}698 \\
(100)\end{array}$ & 0 & 417 & $\begin{array}{l}417 \\
(100)\end{array}$ & $\begin{array}{l}3 \\
(0 \cdot 72)\end{array}$ & 63 & $\begin{array}{c}63 \\
(100)\end{array}$ & 0 & 1178 & $\begin{array}{l}1178 \\
(100)\end{array}$ & $\begin{array}{l}3 \\
(0 \cdot 25)\end{array}$ \\
\hline 5 & Palamaner & 18 & $\begin{array}{r}18 \\
(100)\end{array}$ & 0 & 450 & $\begin{array}{r}450 \\
(100)\end{array}$ & 0 & 206 & $\begin{array}{r}206 \\
(100)\end{array}$ & $\begin{array}{l}2 \\
(0 \cdot 97)\end{array}$ & 23 & $\begin{array}{c}23 \\
(100)\end{array}$ & 0 & 697 & $\begin{array}{c}697 \\
(100)\end{array}$ & $\begin{array}{l}2 \\
(0 \cdot 29)\end{array}$ \\
\hline 6 & Proddutur & 225 & $\begin{array}{r}225 \\
(100)\end{array}$ & 0 & 1651 & $\begin{array}{l}1651 \\
(100)\end{array}$ & 0 & 29 & $\begin{array}{r}29 \\
(100)\end{array}$ & 0 & 34 & $\begin{array}{c}34 \\
(100)\end{array}$ & 0 & 1939 & $\begin{array}{l}1939 \\
(100)\end{array}$ & 0 \\
\hline 7 & Nammakkal & 0 & 0 & 0 & 1106 & $\begin{array}{l}1035 \\
(93 \cdot 6)\end{array}$ & 0 & 261 & $\begin{array}{l}244 \\
(93 \cdot 5)\end{array}$ & 0 & 2 & $\begin{array}{c}2 \\
(100)\end{array}$ & 0 & 1369 & $\begin{array}{l}1281 \\
(93 \cdot 6)\end{array}$ & 0 \\
\hline 8 & CLT\&RI field area & 2 & $\begin{array}{r}2 \\
(100)\end{array}$ & 0 & 350 & $\begin{array}{l}200 \\
(57 \cdot 1)\end{array}$ & 0 & 33 & $\begin{array}{l}22 \\
(66 \cdot 7)\end{array}$ & 0 & 4 & $\begin{array}{c}4 \\
(100)\end{array}$ & 0 & 389 & $\begin{array}{l}228 \\
(58 \cdot 6)\end{array}$ & 0 \\
\hline 9 & Subtotal & 1458 & $\begin{array}{l}1217 \\
(83 \cdot 5)\end{array}$ & 0 & 7583 & $\begin{array}{l}6766 \\
(89 \cdot 2)\end{array}$ & 0 & 1943 & $\begin{array}{l}1630 \\
(83 \cdot 9)\end{array}$ & $\begin{array}{l}5 \\
(0 \cdot 31)\end{array}$ & 340 & $\begin{array}{l}280 \\
(82 \cdot 4)\end{array}$ & 0 & 11,324 & $\begin{array}{l}9893 \\
(87 \cdot 4)\end{array}$ & $\begin{array}{l}5 \\
(0 \cdot 05)\end{array}$ \\
\hline 10 & CLT\&RI outpatient & 97 & $\begin{array}{r}97 \\
(100)\end{array}$ & $\begin{array}{l}2 \\
(2 \cdot 06)\end{array}$ & 281 & $\begin{array}{r}281 \\
(100)\end{array}$ & $\begin{array}{l}4 \\
(1 \cdot 42)\end{array}$ & 984 & $\begin{array}{r}984 \\
(100)\end{array}$ & $\begin{array}{l}28 \\
(2 \cdot 85)\end{array}$ & 0 & 0 & 0 & 1362 & $\begin{array}{l}1362 \\
(100)\end{array}$ & $\begin{array}{l}34 \\
(2 \cdot 49)\end{array}$ \\
\hline 11 & Grand total & 1555 & $\begin{array}{l}1314 \\
(84 \cdot 5)\end{array}$ & $\begin{array}{l}2 \\
(0 \cdot 15)\end{array}$ & 7864 & $\begin{array}{l}7047 \\
(89 \cdot 6)\end{array}$ & $\begin{array}{l}4 \\
(0 \cdot 06)\end{array}$ & 2927 & $\begin{array}{l}2614 \\
(89 \cdot 3)\end{array}$ & $\begin{array}{l}33 \\
(1 \cdot 26)\end{array}$ & 340 & $\begin{array}{l}280 \\
(82 \cdot 4)\end{array}$ & 0 & 12,686 & $\begin{array}{r}11,255 \\
(88 \cdot 7)\end{array}$ & $\begin{array}{l}39 \\
(0 \cdot 35)\end{array}$ \\
\hline
\end{tabular}

$\mathrm{R}$, registered; E, examined; p, positive; Figures in brackets are percentages. 
POSITIVITY AND TYPE OF DISEASE

All types of PB leprosy cases except $\mathrm{PN}$ showed positivity ranging from $0.06 \%$ in TT to $1 \cdot 26 \%$ in BT when results from all cases were taken together. However, the smears from I, TT \& PN from all LCUs (including field operational area of CLT\&RI) were reported negative. Only 2 LCUs out of the 8 reported positivity and they were $0 \cdot 25 \%$ and $0 \cdot 29 \%$ in Pileru and Palamaner respectively. The positivity of smears from OPD of CLT\&RI ranged from $1 \cdot 42 \%$ in $\mathrm{TT}$ cases to $2 \cdot 85 \%$ in $\mathrm{BT}$ cases.

\section{TYPE DISTRIBUTION OF SKIN SMEAR EXAMINED CASES}

Of the 11,255 cases examined for skin smear bacteriology $11 \cdot 7 \%, 62 \cdot 6 \%, 23 \cdot 2 \%$ and $2 \cdot 5 \%$ belonged to I, TT, BT and P N respectively. The proportion of different types ranged from 0 to $40 \cdot 4 \%, 20 \cdot 6 \%$ to $96 \cdot 7 \%, 1 \cdot 5 \%$ to $72 \cdot 2 \%$ and 0 to $6 \cdot 2 \%$ in different centres for I, TT, $\mathrm{BT}$ and PN respectively.

BACTERIOlOGiCAl index (BI) OF POSitive CASES (Table 2)

Of the 39 positive cases, the BI at any one site was more than $1+$ on Ridleys scale in only 11 cases $(28 \cdot 2 \%)$. All the cases with a BI of more than $1+$ belonged to the BT group.

\section{DISCUSSION}

Skin smear bacteriological positivity in the PB group of leprosy patients has been reported as high as $21.8 \%$ with a $\mathrm{BI}$ of $1+$ on Ridleys scale. ${ }^{8}$ However, it was reported in

Table 2. BI of positive cases

\begin{tabular}{|c|c|c|c|c|}
\hline \multirow[b]{2}{*}{ BI* } & \multicolumn{3}{|c|}{ Type } & \multirow[b]{2}{*}{ Total } \\
\hline & I & TT & BT & \\
\hline $1+$ & 2 & 4 & 22 & $\begin{array}{c}28 \\
(71 \cdot 8)\end{array}$ \\
\hline $2+$ & - & - & 7 & $\begin{array}{c}7 \\
(17 \cdot 9)\end{array}$ \\
\hline $3+$ & - & - & 4 & $\begin{array}{c}4 \\
(10 \cdot 3)\end{array}$ \\
\hline Total & $\begin{array}{l}2 \\
(5 \cdot 1)\end{array}$ & $\begin{array}{c}4 \\
(10 \cdot 3)\end{array}$ & $\begin{array}{c}33 \\
(84 \cdot 6)\end{array}$ & $\begin{array}{c}39 \\
(100)\end{array}$ \\
\hline
\end{tabular}

* Maximum bacteriological index at any examined site.

Figures in brackets are percentages. 
the same study that relapses could not be correlated with the initial bacteriological status using three different drug regimens including the WHO recommendation, at $3 \frac{1}{2}$ years follow-up. Interobserver variation in reading the smears as negative while actually they are positive and vice versa has also been reported to the extent of $5 \cdot 6 \%$ and $2 \cdot 3 \%$ respectively. ${ }^{9}$ The weakness and shortcomings in laboratory services are by no means new; they have been continuously identified over 20 years in numerous publications in leprosy and tuberculosis literature and this situation is unlikely to improve to the desired standards. ${ }^{10}$ Organizing bacteriological examination of skin smears of all cases has been identified as a bottleneck by successive independent evaluation teams in India. ${ }^{11-13}$ The bulk of the new leprosy cases detected (70-80\%) belong to the PB group. In the present analysis, about $22 \cdot 2 \%$ were found to be of the BT type. Under field conditions, it is only $0.31 \%$ of BT type and $0.05 \%$ of all types of the PB group that were found to be bacteriologically positive and none of the I, TT and PN group were positive. It is evident from the observations of successive independent evaluation team reports that perhaps it is almost impossible to improve the laboratory services in a mass control programme. The question is, with the very low positivity rates that are obtained above under field conditions, whether it would be worthwhile to carry out routine skin-smear examination in the PB group of leprosy patients in a mass control programme? It appears, perhaps, that it is not necessary to do skin smear bacteriology as a routine in all new PB group of patients, except BT type, especially when they are clinically confirmed by a medical person before commencement of treatment. Even under ideal conditions such as the OPD of CLT\&RI, which can not be produced in field laboratories, the overall positivity was only $2 \cdot 49 \%$. Surveillance after release from treatment with MDT regimen is more or less mandatory for a period of 2 years in all control programmes. As such even those few cases which should have received MB MDT, had the bacteriological positivity been detected bef ore commencement of treatment, could be taken care of during the surveillance period by way of detecting signs of clinical activity of the disease and instituting necessary MB treatment.

At present a lot of time is being spent by laboratory technicians on collection and examination of skin smears of PB leprosy patients, with a limited purpose served considering the effort involved, since nearly $70 \%$ to $80 \%$ of the new cases belong to this group. Further, if this routine examination is given up, they may well spend their time on bacteriological examination of $\mathrm{MB}$ cases, where it is actually needed for monitoring response to chemotherapy and deciding the time of release from treatment (RFT). Other advantages in giving up this routine examination are:

1 the saving of resources;

2 possibly better compliance of patients to clinic attendance;

3 saving the patients from unnecessary inconvenience due to pain; and

4 preventing the patients from possible exposure to AIDS, hepatitis B etc., due to faulty sterile techniques.

\section{Conclusion}

Skin smear bacteriological examination is perhaps not necessary in the PB group of newly detected leprosy patients (except the BT group) as a routine in a mass control programme when the clinical confirmation of diagnosis is made by a medical person. 
There are several advantages if the above examination is given up, without jeopardizing the interests of the individual patient seriously.

Further analysis using more extensive data would be useful in identifying which of the BT cases would need smear examination with reference to clinical features.

\section{Acknowledgments}

We would like to extend our sincere thanks to the district leprosy officers and medical officers of the leprosy control units at Krishna, Cudappa and Chittoor disticts for providing us with the required data. We would like to thank the Head of Division of the laboratories and Mr T K Ramasamy, laboratory technician, of CLT\&RI for collecting and furnishing data of OPD. Thanks are also due to Mr M Mohan, Steno and Mrs R Lakshmi for secretarial assistance.

\section{Ref erences}

1 WHO Study Group. Chemotherapy of leprosy for control programme. Technical Report Series. No.675. WHO: Geneva, 1982, pp. 22.

2 Guidelines for multidrug treatment in endemic districts. Natural Leprosy Eradication Programme, Directorate General of Health and Family Welfare, Nirman Bhavan, New Delhi, 1989, pp. 27.

3 WHO Expert Committee on LepFöōy. Sixth Report. Technical Report Series No. 768, WHO: Geneva, 1988, pp. 15.

4 Dharmendra. Leprosy, Vol 1, 1st ed. Bombay, India, 1978, pp. 46 and 56.

5 Jopling WH. Handbook of Leprosy, 3rd ed. Heineman, London, 1984, pp. 42.

6 Thangaraj RH. A Manual of Leprosy, 3rd ed. New Delhi, India, 1983, pp. 79.

7 Hastings RC. Leprosy, 1st ed. Hong Kong, 1985, pp. 144-6.

8 Kiran Katoch et al. Relapses in paucibacillary patients af ter treatment with short term regimens containing rifampicin. Int J Lepr, 1989; 57: 45\&64.

9 Vettam L, Pritze S. Reliability of skin smear result experience with quality control of skin smears in different routine services in leprosy control programme. Lepr Rev, 1989; 60: 187-97.

10 Georgiev GD, McDougall AC. The bacteriological examination of slit-skin smear in leprosy control programmes using multiple drug therapy: a plea for radical changes in current operational methodology. Ind J Lepr, 1987; 59: 373-85.

11 National Leprosy Eradication Programme in India. Report of Independent Evaluation Team, Ministry of Health and Family Welfare, Nirman Bhavan, New Delhi, 1986, pp. 26-7.

12 National Leprosy Eradication Programme in India. Report of second independent evaluation, Ministry of Health and Family Welfare, Nirman Bhavan, New Delhi, 1987, pp. 27-9.

13 National Leprosy Eradication Programme in India. Report of third independent evaluation, Ministry of Health and Family Welfare, Nirman Bhavan, New Delhi, 1990, pp. 22, 33-4.

\section{L'examen bactériologique par la méthode des frottis cutanés est-il nécessaire chez tous les patients lépreux paucibacillaires dans le cadre des programmes de contrôle à grande échelle?}

\section{P S Rao V Ekambaram, B N Reddy, P Krishamoorthy, S K Suresh Kumar Et A Dutta}

Résumé Entre 1987 et 1989 furent recueillis et analysés les résultats de l'examen bactériologique par frottis cutanés de 11.255 lépreux paucibacillaires provenant de 8 centres de contrôle de la lèpre dans le cadre du Programme national d'Eradication de la Lèpre (NLEP) dans le sud de l'Inde et des consultations hospitalières extemes OPD de l'Institut central de Recherche et d'Enseignement de la Lèpre (CLT\&RI) à Chengalpattu. Seuls 
$0,05 \%$ des frottis provenant des centres de contrôle de la lèpre et $2,49 \%$ provenant des consultations hospitalières externes du CLT\&RI se sont avérés positifs. Aucun fottis du type lèpre indéterminée, LT ou purement névritique provenant des 8263 patients examinés ne s'est avéré positif sur le terrain. L'importance des examens bactériologiques de routine dans le cadre des programmes de contrôle de la lèpre à grande échelle est discuté.

\title{
¿Es el examen bacteriológico del frotis de piel necesario en todos los pacientes leprosos paucibacilarios en los programas de control en masa?
}

\author{
P S Rao, V Ekambaram, B N Reddy, P Krishnamoorthy, S K Suresh Kumar \\ Y A Dutta
}

Resmuen Se recolectaron y analizaron los resultados de los exámenes bacteriológicos de los frotis de piel de 11.255 pacientes leprosos paucibacilarios de 8 unidades de control de lepra bajo el Programa Nacional de Erradicación de la Lepra (NLEP) en el Sur de la India y el Departamento de Pacientes Ambulatorios (OPD) del Instituto Central de Investigación y Enseñanza de la Lepra (CLT\&RI), Chengalpattu, entre 1987 y 1989 . Sólo el $0,05 \%$ de los frotis de las unidades de control de la lepra y el $2,49 \%$ de OPD de CLT \& RI fueron encontrados ser positivos. Ni siquiera un frotis de lepra de tipo indeterminado, tuberculoide o puramente Neuritico de 8263 casos examinados se encotró que era positivo en las condiciones de estudio. Se discute la relevancia de llevar a cabo exámenes bacteriológicos de rutina como una rutina en los programas de control de la lepra en masa. 